\title{
Correction to: Can anti-corruption improve the quality of environmental information disclosure?
}

\author{
Ye Wei ${ }^{1} \cdot$ Wenjian $\mathrm{He}^{1,2}$ \\ Published online: 30 August 2021 \\ (C) Springer-Verlag GmbH Germany, part of Springer Nature 2021
}

\section{Correction to: Environmental Science and Pollution Research}

https://doi.org/10.1007/s11356-021-15932-w

The article Can anti-corruption improve the quality of environmental information disclosure? by Ye Wei \& Wenjian He, was originally published online on 21 August 2021 with Open Access under a Creative Commons Attribution 4.0 International License, which permits use, sharing, adaptation, distribution and reproduction in any medium or format, as long as you give appropriate credit to the original author(s) and the source, provide a link to the Creative Commons license, and indicate if changes were made. The images or other third party material in this article are included in the article's Creative Commons license, unless indicated otherwise in a credit line to the material. If material is not included in the article's Creative Commons license and your intended use is not permitted by statutory regulation or exceeds the permitted use, you will need to obtain permission directly from the copyright holder. To view a copy of this license, visit http:// creativecommons.org/licenses/by/4.0.

With the author's/authors' decision to cancel Open Access the copyright of the article changed on 25 August 2021 to () Springer-Verlag GmbH Germany, part of Springer Nature 2021 with all rights reserved.

The Original article has been corrected.

Publisher's note Springer Nature remains neutral with regard to jurisdictional claims in published maps and institutional affiliations.

The online version of the original article can be found at https://doi.org/ 10.1007/s11356-021-15932-w

Wenjian He

hewenjian@126.com

Ye Wei

weiye824@163.com

1 Business School, Nanjing University of Information Science \& Technology, Nanjing 210044, China

2 Development Institute of Jiangbei New Area, Nanjing University of Information Science \& Technology, Nanjing 210044, China 